'Under the Mediterranean' The Honor Frost Foundation Conference on Mediterranean Maritime Archaeology 20th - 23rd October 2017 Short Report Series.

doi: https://doi.org/10.33583/utm2020.05

(C) 2020 The Author

\title{
Mixed Cargoes in the Western Mediterranean during Late Antiquity: the Messina 1 shipwreck
}

\author{
C. Bazzanoa, T. Gambinb, R. LaRoccac \\ a Universita’ di Sassari, cristinabazzano@gmail.com \\ bUniversity of Malta, timmy.gambin@um.edu.mt \\ cSoprintendenza del Mare, robertolarocca66@libero.it
}

The Atlantis Project consisted of undersea mapping activities deep water surveys - through the use of remotesensing systems, mainly side-scan sonar, and a remotely operated vehicle (ROV). The results of these investigations culminated in the discovery of three shipwrecks, named Messina 1,2 and 3. Messina 1 lies at a depth of $93 \mathrm{~m}$, and consists of a low mound of mixed amphorae. Five complete examples were recovered for further study. Upon closer examination, the typologies point to a connection between the North African area and the Iberian Peninsula. The aim of this brief report is to provide a better understanding of the origin and type of the ship's cargo.

\section{Key words}

Roman Shipwreck, Messina, Sicily, Deep water shipwreck, amphora studies, Ancient Trade routes

The Atlantis Project, kicked off in 2010 through the joint efforts of the Sicilian Region - Superintendence of the Sea, the Aurora Trust Foundation, Oloturia sub, Bimaris Edizioni and the Commune of Messina. The initial task undertaken was the mapping of the seabed of the north east coast of the Messina Province. Technologies used included Side Scan Sonar and a Remote Operated Vehicle followed by dives on the site using technical divers. 
The 2011 season permitted the completion of approximately a 40 square kilometer area in which 18 potential targets were identified (Fig. 1). Of these, three were earmarked as being of high interest and were re-scanned using high-resolution side-scan sonar. Once completed, these surveys highlighted the presence of three targets of high potential lying at depths of between 90 and 120 metres. These targets were labelled Messina 1, 2 and 3 respectively. A further research campaign was conducted in 2015 in collaboration with the University of Messina (Ar.Bio.Me.), with specific focus on the wreck Messina 1 (Fig. 2). In 2015, high-resolution video was used for detailed documentation of the cargo and the production of a 3D model. Moreover, five samples were recovered thus providing a corpus of material data that are representative of the cargo. The purpose of this contribution is to give a preliminary overview of the nature and origin of the cargo and to place these within the broader context of Mediterranean trade routes.

\section{The Vessel}

Lying on a flat sandy seabed, the visible part of the cargo measures approximately $15 \mathrm{~m}$ long and $5 \mathrm{~m}$ wide. The location of this shipwreck is in an area that is highly susceptible to peculiar weather conditions, albeit on a wellestablished sailing route along the northern coast of Sicily. Oval in shape, the amphora-mound measures not more than $1.5 \mathrm{~m}$ at its highest point. It is clear that the objects form the upper middle part of the cargo, which was stacked in two or three overlapping layers. The edges of the mound have lost their original orientation due to the collapse of the wooden hull brought about by the shipworm teredos navalis

Given the layout of the cargo, it would be reasonable to assume that the ship may only have been decked at its extremities - but this hypothesis has yet to be confirmed. To date, nothing of the wooden hull remains has been detected but there can be little doubt that at least part of the structure is present in the seabed sediments.

\section{The Objects}

Of the five samples recovered in 2015, three turned out to be of North African origin with the other two being of Iberian origin. The North African amphorae were identified as Dressel 30 (No. 1) and Africana IIC (Nos 4 and 5) respectively. On the other hand, the Iberian types (here identified with numbers 2 and 3), despite a variation in size, were determined to be of the Almagro Type 50. Due to the heavy concretions present on the objects it was impossible to study the clay in detail. It was therefore necessary to base our identifications solely on the shapes.

\section{Amphora Typologies}

Amphora n. 1 (Fig. 3) is heavily concreted and has a piriform body, marked by very pronounced horizontal grooves. The neck and the rim are flush, the lip is moulded with a quadrangular section. The handles are curved are attached to the base of the neck and shoulder. The base is somewhat quadrangular and slightly concave in shape. Based solely on the shape-analysis, this amphora is typically referred to as the type Dressel 30/Keay 1984 - type I B / type 60 Bonifay (Keay, 1984: 95; Bonifay, 2004: 148). According to Bonifay, this type can be 
considered an African imitation of flat-based types from Gaul (Carandini et al., 1972: 600-605; Carandini et al., 1977: 149-151). The production of this type is believed to have taken place in North Africa from the end of the 2nd to the second half of the 4th century AD. Based on petrological studies carried out it has been determined that the area of production is Mauretania and present-day Tunisia. In all probability this type of container was used for the transport of olive oil (Bonifay, 2004: 148).

The type being presented here (represented by nos 2 and 3) are of Iberian production (Fig. 4). These amphorae have a cylindrical body with a very flared neck, extending outwards and slightly convex on the interior. The neck is wide, short and truncated, the handles are short and are set between the top of the rim and the shoulder. They are elliptical in section and are distinguished by a slight depression in the centre. The base is characterized by the body falling away from the main section of the object and is cylindrical from the inside. Again, on the basis of shape - both these objects can be identified as Almagro 50/Keay 1984, type XXII (Carandini et al., 1972: 460-633; Carandini et al., 1977: 117-254; Keay 1984: 169). The origin of this type of amphora is attested in a number of production-centres in southern Spain and Portugal. Basing his conclusions on clay samples from this typology, Keay also proposed a north African origin (Keay, 1984: 170; Fabião, 2008: 513). Some shipwrecks have brought to light evidence for the transport of fish sauces in this type of amphora (RandelloRagusa wreck, Parker, 1992: 364). The proposed chronology for the production of this typology varies from the beginning of the 4th century and the first half of the 5th century AD (Benoit, 1962: 161).

Objects 4 and 5 have a body that is broad and cylindrical (Fig. 5). The rim is rounded outward, slightly convex inside with an almond-shaped section. The neck is narrow, short and truncated. The 'ear-shaped' handles have an elliptical section and are set just under the neck extending to the shoulder base. The base is truncated and conical with full and rounded ends. These characteristics facilitated the identification of these objects as being African Type II C (Keay 1984: 118; type V; var. 1 identified by Manacorda). The proposed chronology for the production of this typology varies from the middle of the 3rd century to the end of the 4th century AD (Keay 1984: 118; Bonifay 2004: 115). Production has been identified in the Nabeul area, where many specimens have been excavated and studied (Bonifay 2004: 112). It is accepted that these containers were used for the transport of salsamenta (Keay, 1984: 118; Bonifay, 2004: 115).

\section{Discussion}

Wrecks of ships that were carrying a variety of amphora types clearly indicate that mixed cargoes were not exceptional and must be seen as an indicator of maritime trade and connectivity in the 4th century AD (Volpe, 2002: 240). Other wrecks with similar assemblages to that of Messina I have been located and studied. Cala del Lazzaretto A in Alghero (SS) and the Planier 7 wreck along the coast of the island of the same name, the Anse Gerbal 1 wreck found off Port-Vendres. 
Cala del Lazzaretto A site consisted of a load of Almagro 50 amphorae with evident traces of fish in brine and African Dressel 30 types that were generally used for the transport of garum (Gavini, Riccardi, 2011: 276). The Planier 7 wrecksite was also composed of Almagro Type 50, again with traces of brine. Also present at this site were amphorae of the Type Africana II (Benoit, 1962: 157-159; Parker, 1992: 317-318). Finally, Anse Gerbal I consisted of north African, late-imperial Almagro 50-51 amphorae (Liou, 1975: 571-573; Parker, 1992: 329$330)$.

Within mixed cargoes of amphorae carrying fish products - Iberian typologies are predominantly of a secondary nature (quantitively) when compared to North African types (Auriemma et al., 2012: 168). It is also pertinent to point out that, based on shipwreck evidence, the circulation of these specific cargoes significantly decreases towards the end of the 4th century AD (Distefano, 2002: 680).

There are a number of other shipwrecks that consist exclusively of Lusitanian amphorae of the Almagro Type 50. Taking into account some subdivisions and morphological variants (Parker, 1989: 653), there are four cases which can be found in the literature. These are as follows: Randello Relief (Rg) (Parker, 1989), Relation of Maratea (RC) (Parker, 1992: 259), Zirje wrecksite in Croatia (Parker, 1992: 458), and the wreck of No-Cagliari (Parker, 1992: 290).

Given the almost-exclusive transport of Lusitanian fish sauce in Almagro 50 amphorae during the 4th century (Distefano, 2002: 641), the distribution of these amphorae in the central Mediterranean may be considered as an indicator of an evolving historical/commercial reality of the Mediterranean basin.

Analysis of the amphora types from Messina 1, and comparison of these with other shipwrecks permits some tentative considerations of areas of production, maritime routes, and centres of consumption in the early 4 th century AD.

A strong presence of mixed cargoes vis-a-vis shipwrecks loaded with an exclusive amphora are indicative of modified and evolving trade patterns, reflecting the renewed production of fish products in Lusitania, Baetica, and north Africa. Commercial trade in the late Roman era throughout the Mediterranean basin is still characterized by long-distance exchange and networks albeit less direct and on a smaller scale (Leidwanger, 2014: 33).

\section{Acknowledgements}

We wish to thank the AURORA Trust and Oluturiasub for their contribution to the Atlantis Project.

\section{References}


Auriemma, R., Degrassi, V., Quiri, E., 2012, Produzione e circolazione di anfore in Adriatico tra III e IV secolo: dati da contesti emblematici, in C.S. Fioriello (ed.), Ceramica romana nella Puglia adriatica: 255-298. Bari, Sedit.

Benoit, F., 1962, Nouvelles épaves de Provence. III. Gallia 20.1: 147-176.

Bonifay, M., 2004, Études sur la céramique romaine tardive d'Afrique. Oxford, British Archaeological Reports International Series 1301.

Carandini et al., 1972, Ostia III. Studi Miscellanei 21. Roma, L’Erma di Bretschneider.

Carandini et al., 1977, Ostia IV. Studi Miscellanei 23. Roma, De Luca editore.

Distefano, G., 2002, Marmi africani e garum spagnolo nel Mediterraneo centrale: tracce di alcune rotte commerciali di età romana, in M. Khanoussi, P. Ruggeri and C. Vismara (eds), L'Africa romana. Atti del $14^{\circ}$ Convegno di studio, 627-642. Roma, Carocci editore.

Fabião, C., 2008, Las ánforas romanas de Lusitania, in D. Bernal Casasola and A. Ribera i Lacomba (eds), Cerámicas hispanorromanas. Un estado de la cuestió, 501-521. Cadiz, Universidad de Cádiz, Servicio de Publicaciones.

Gavini, V. F. and Riccardi, E., 2011, Il relitto del IV secolo d.C. di Cala del Lazzaretto-Alghero (SS). Erentzias I, 269-281. Sassari, Carlo Delfino editore.

Keay, S. J., 1984, Late Roman Amphorae in the Western Mediterranean. Oxford, British Archaeological Reports International Series 196.

Leidwanger, J., 2014, Maritime networks and economic regionalism in the roman eastern Mediterranean. Les nouvelles de l'archéologie 135, 32-38.

Liou, B., 1975, Informations archéologiques. Direction des recherches archéologiques sous-marines. Gallia 33, 571-605.

Panella, C., 2002, Le anfore di età imperiale nel Mediterraneo occidentale, in Céramiques héllenistiques et romaines 3: 177-275. Besançon, Presses Universitaires Franc-Comtoises. 
Parker, A. J., 1989, Amphores Almagro 50 de l'épave de Randello (Sicile), in Amphores romaines et histoire économique. Dix ans de recherche. Actes du colloque de Sienne Française de Rome, 650-653. Roma, École Française de Rome.

Parker, A. J., 1992, Ancient shipwrecks of the Mediterranean and the roman provinces. Oxford, British Archaeological Reports International Series 580.

Tisseyre, P., 2010, Ritrovamenti nelle acque della Provincia di Messina Isole Eolie 2004-2010, in Atti del $4^{\circ}$ Convegno nazionale di archeologia subacquea. Genova.

Volpe, G., 2002, Relitti e rotte commerciali nel Mediterraneo occidentale tardoantico, in M. Khanoussi, P. Ruggeri and C. Vismara (eds), L'Africa romana. Atti del $14^{\circ}$ Convegno di studio, 239-250. Roma, Carocci editore. 


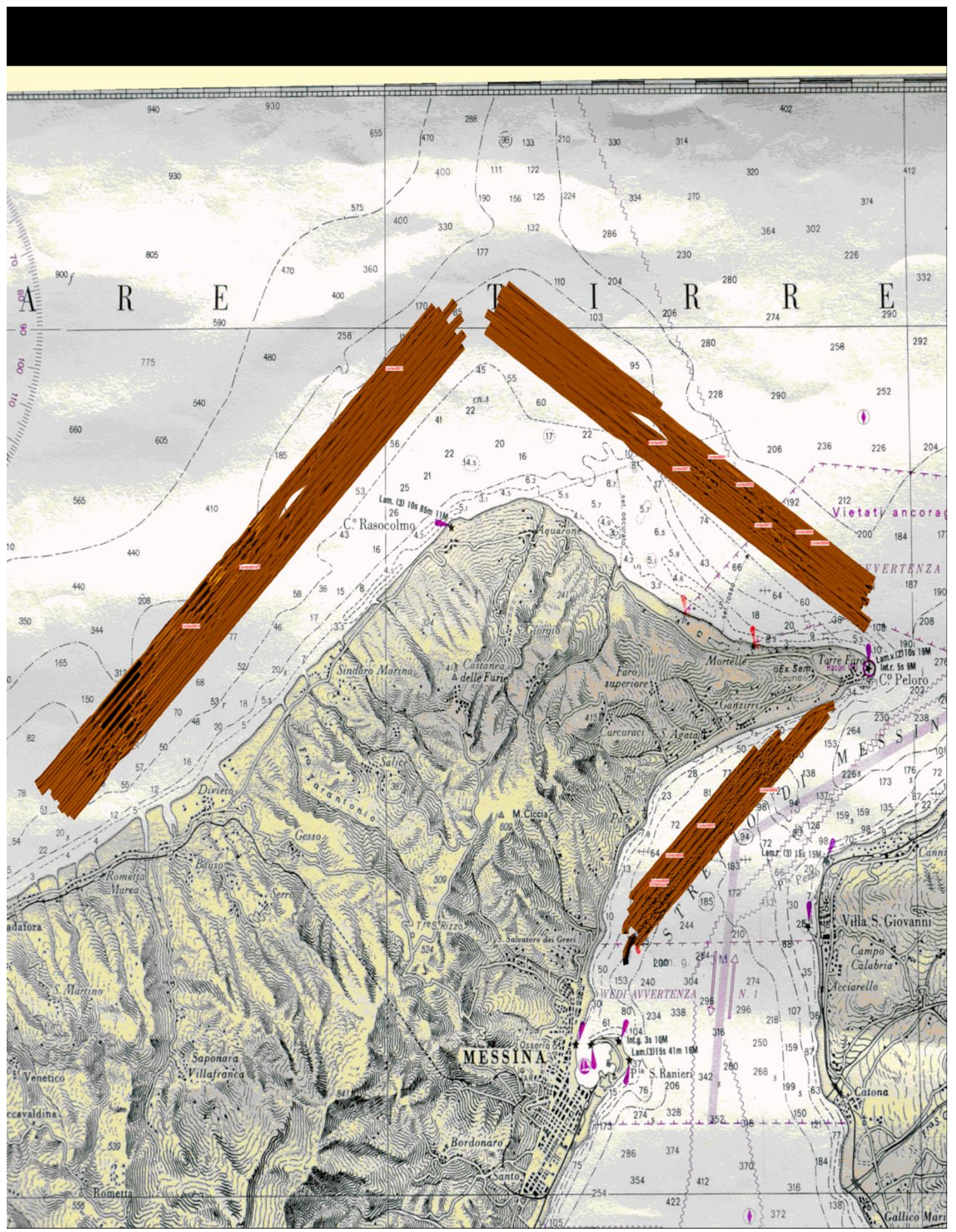

Fig. 1 


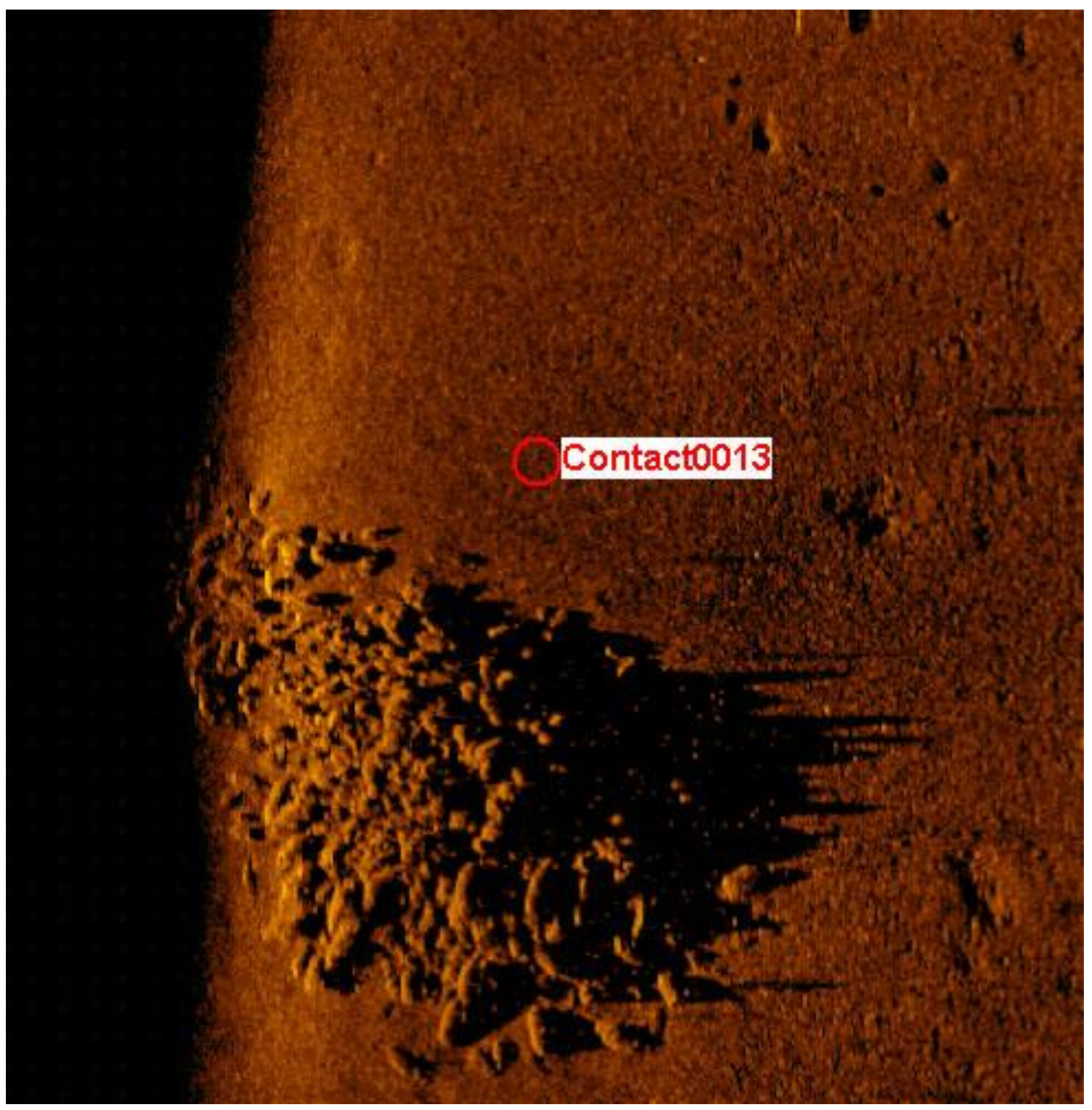

Fig. 2 


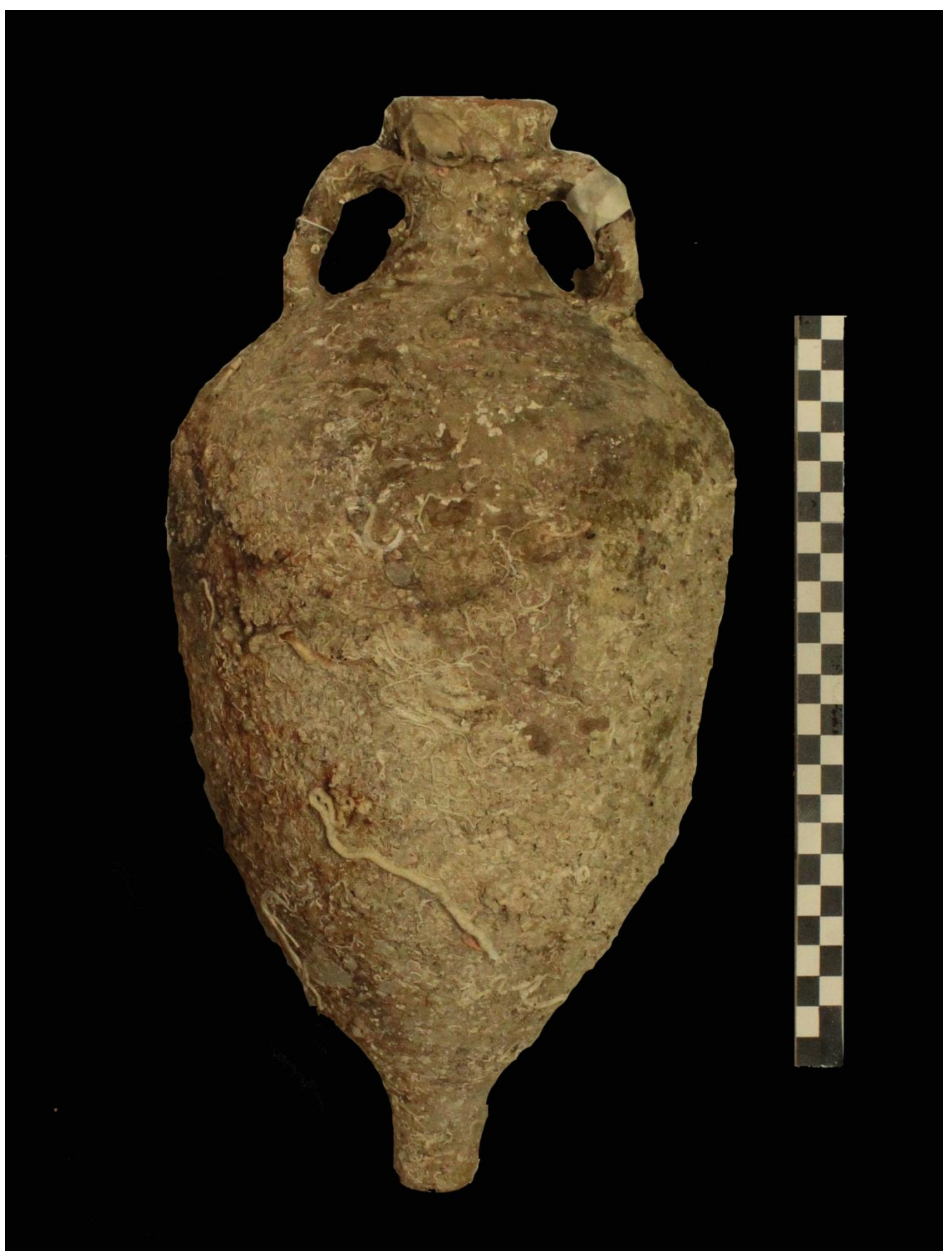

Fig. 3 


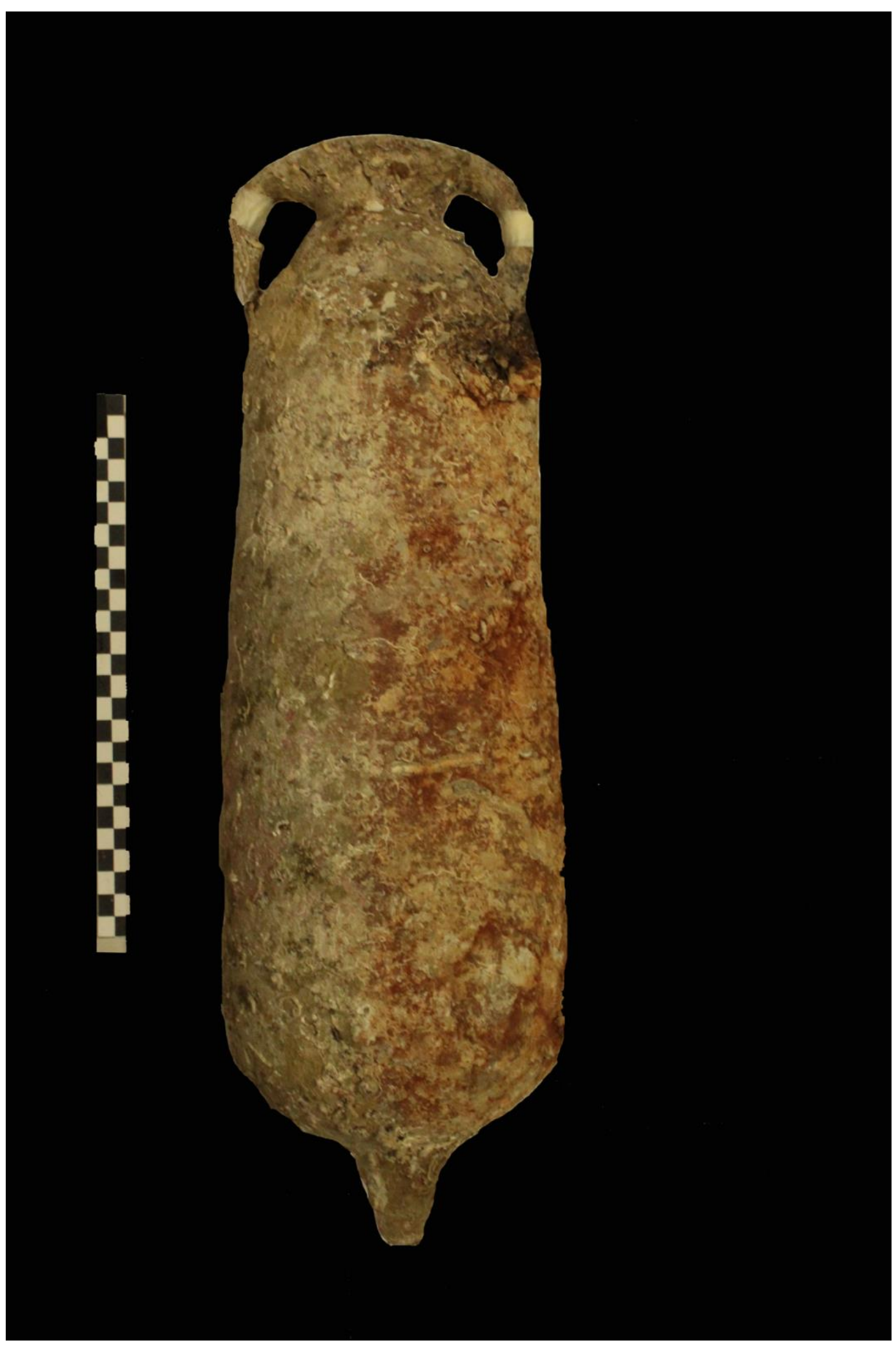

Fig. 4 


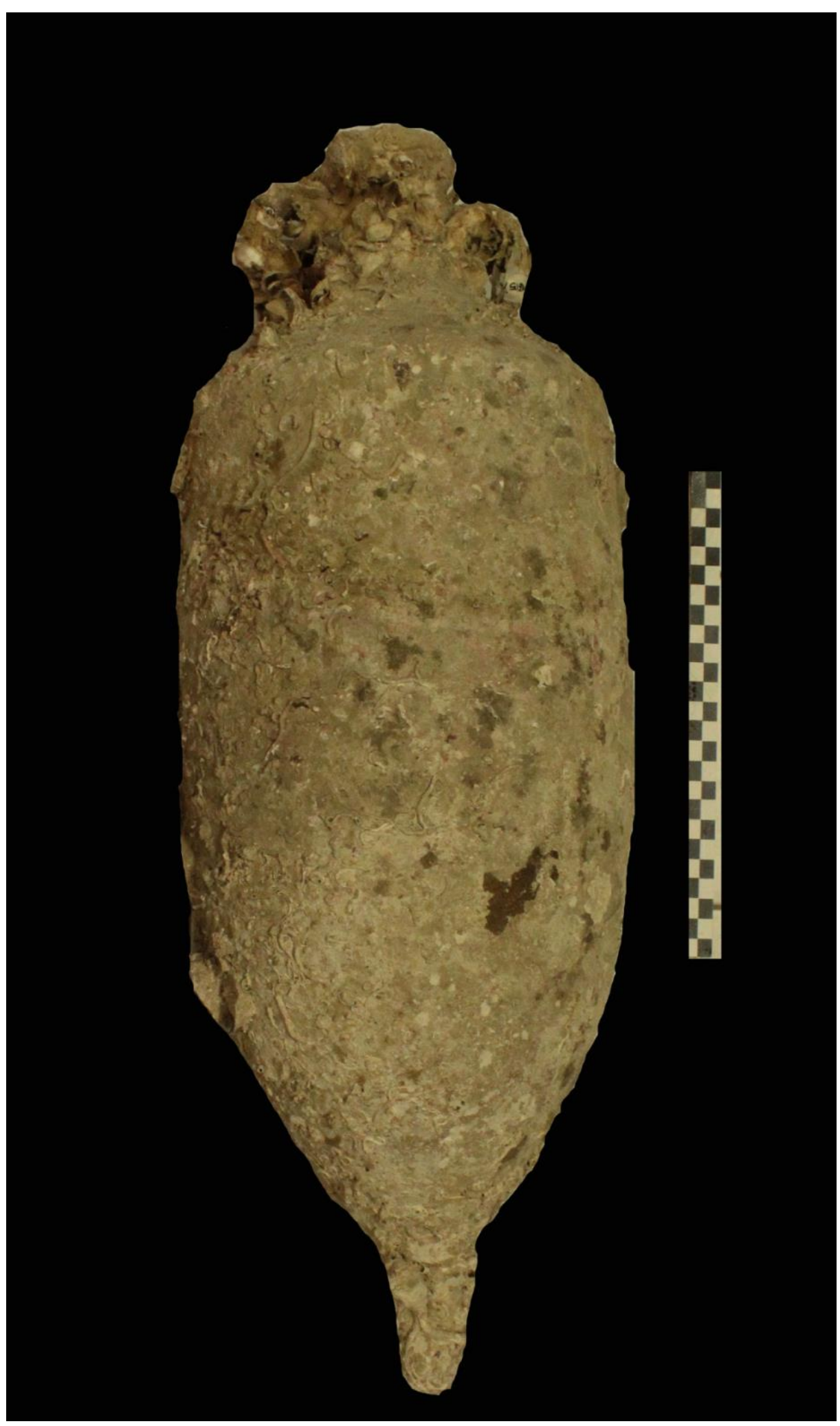

Fig. 5 